\title{
DIZZYING DIALOGUE: CANADIAN COURTS AND THE CONTINUING JUSTIFICATION OF THE DISPOSSESSION OF ABORIGINAL PEOPLES
}

\section{D'Arcy Vermette}

Since Aboriginal rights have found protection within Canada's Constitution, a new relationship has emerged between Canada's Aboriginal Peoples and the Crown. This relationship is characterized by the need for "reconciliation." In its growing jurisprudence, the Supreme Court of Canada applies reconciliation doctrine to several important Aboriginal claims. Each application, however, brings with it a restriction on Aboriginal rights. This paper argues that the Court's conception of reconciliation is designed to facilitate the integration of Aboriginal peoples into larger society rather than to protect their collective interests. To demonstrate this argument, this paper examines the Supreme Court's discussion of the doctrine of reconciliation from Sparrow (1990) to Little Salmon (2010).

Depuis que les droits des autochtones sont protégés par la constitution canadienne, une nouvelle relation, ayant comme caractéristique le besoin de "réconciliation », a vu le jour entre les peuples autochtones du Canada et la Couronne. La Cour suprême du Canada a appliqué la doctrine de la réconciliation dans la série d'arrêts où elle s'est penchée sur plusieurs importantes revendications autochtones. Dans chaque cas, l'application de la doctrine de la réconciliation a cependant abouti à une restriction des droits des autochtones. Dans cet article, l'auteur soutient que, dans l'esprit de la Cour, la réconciliation vise à faciliter l'intégration des peuples autochtones dans la société en général plutôt qu'à protéger leurs intérêts collectifs. Pour étayer cette opinion, il examine l'analyse qu'a faite la Cour suprême de la doctrine de réconciliation de l'arrêt Sparrow (1990) à l'arrêt Little Salmon (2010).

Of the Métis Nation. Assistant Professor, Native Studies Programme, St. Thomas University LL.D. Candidate, LL.M., LL.B., B.A. (Native Studies). Thank you to Reem Bahdi for the helpful editorial suggestions and for showing patience in seeing my work to the finish line. This paper is dedicated to the memory of Patricia Monture. When I was an undergraduate student, Patricia showed me that the power of Aboriginal understanding does not lie within the minutiae of our individual experience (for these are symptomatic responses) but in our ability to build an intellectual understanding of the forces which disempower our People(s). Her message was one which provided a way forward for the judiciary and which was artfully captured in her writing. Thank you, Trisha, for your teachings and inspiration. 
Canadians must carefully examine their past and present relationships with Aboriginal Peoples in an effort to take themselves to the place where they understand what is required to move beyond the colonial relations on which the country is based.

\section{INTRODUCTION}

Studying, researching, and writing about Aboriginal law can be a grinding and exhausting experience. Try as Aboriginal scholars and commentators might to encourage Canadian courts to approach their relationship with Aboriginal peoples in a different, non-colonialist light, it appears that very little listening is taking place. Instead, courts adopt language and propose concepts that appear enlightened on their face but that actually are limited to formalizing the process of colonization. Colonialism "exploits the oppressed people, destroying their national society and replacing Indigenous cultures." This exploitation is achievable because Aboriginal peoples are made into objects that, dehumanized, are easily exploitable and dominated. "Under colonialism society is transformed...The imperialists produce and appropriate economic surpluses that set into motion inferior class and cultural inferiority of the Indigenous population." ${ }^{3}$ Domination becomes the key factor applicable to the virtual totality of Aboriginal/newcomer relations.

"Reconciliation" has recently emerged as an overarching theme in Aboriginal law. While reconciliation is undoubtedly a nice, attractive word, no reconciliation is actually taking place or being built as a result of or in relation to Canada's laws concerning the rights of Aboriginal peoples. ${ }^{5}$ On the contrary, in recent years Canada's courts have created and interpreted a principle of reconciliation which embodies (some) nice language but offers little reconciling substance. Canadian courts are confused (or dishonest) because '[i]n 'truth'... there never was any 'conciliation' to 're", This paper discusses the court's interpretation, and misapplication of the reconciliation principle; it reveals a process of domination within the realm of reconciliation.

When Aboriginal rights were enshrined in the Constitution in 1982, it was an act of redress which had the potential to open the doors to a broader reconciling process. But reconciliation was not the legal buzz word of the time. Reconciliation only emerged as a legal principle when constitutionally protected Aboriginal rights reached the Supreme Court of Canada in 1990. The Supreme Court of Canada

\footnotetext{
Patricia Monture-Angus, Journeying Forward: Dreaming First Nations' Independence (Halifax: Fernwood Publishing, 1999) at 22.

2 Howard Adams, Tortured People: The Politics of Colonization, revised ed. (Penticton, B.C., Theytus Books Ltd., 1999) at 6.

Ibid.

Ibid at 7.

5 While this paper is about the case law, reconciliation is occurring in other contexts. For a look at the Government of Canada's attempt at reconciliation in regards to residential schools, see R. Chrisjohn \& A. Bear Nicholas, et al. "An Historic Sort-of-Apology, Completely and Utterly Not Accepted" online: The Marxism Mailing List <http://www.marx- mail.org/Apology-NotAccepted.htm>.

$6 \quad$ Ibid.
} 
introduced reconciliation with a coherent vision. Indeed, the language of the Sparrow $^{7}$ decision, bears witness to this vision. But post-Sparrow, the Supreme Court began to apply reconciliation in a variety of ways, each of which diverted considerably from the Sparrow approach.

This paper offers a critique of the Supreme Court of Canada's doctrine of reconciliation from its beginnings in Sparrow to its most recent application in Little Salmon. ${ }^{8}$ Little Salmon cannot be understood without the legal context which preceded it. This paper establishes the proper jurisprudential context for Little Salmon by demonstrating how the Court's colonialist understanding of reconciliation has led to yet another defeat for Aboriginal issues in Canadian courts. Part II of this paper unpacks the various ways in which the Supreme Court of Canada interprets the principle of reconciliation by following the evolution of the principle in key Aboriginal rights decisions. It argues that reconciliation represents an arbitrary creation of the court. As a principle, it remains disconnected from Aboriginal aspirations and has in fact produced the continued dispossession of Aboriginal peoples through law. Part III examines how the doctrine of reconciliation has played out in regards to duties owed to Aboriginal Peoples. It follows the doctrine of reconciliation through the major cases on the duty to consult which culminates in the Little Salmon decision. Here it is argued that the way in which reconciliation is employed by the Court illustrates the arbitrariness of the principle and the unwillingness of the Court to compromise its colonial mentality.

\section{THE PARADOX OF THE DOCTRINE OF RECONCILIATION ${ }^{9}$}

The principle(s) of reconciliation as articulated by the Supreme Court has received insufficient academic attention in Canada, although two scholars have examined the important concept in some detail. Professor Kent McNeil has explored the conflicting notions of reconciliation articulated in the majority opinions articulated by Chief Justice Lamer as compared to the dissenting opinions of current Chief Justice McLachlin. ${ }^{10}$ McNeil concludes that McLachlin's views are "more in keeping with the constitutional principles that should govern the relationship between Aboriginal peoples and the Crown." "Professor McNeil has adequately explored the inner conflict of the Court and I do not intend to repeat that work although I do discuss Chief Justice McLachlin's dissenting opinion in the Van der Peet ${ }^{12}$ trilogy of cases in my own analysis. While I draw inspiration from McNeil's approach and analysis of the Lamer-McLachlin debate, I go beyond this internal debate and examine a larger swath of Canadian jurisprudence.

\footnotetext{
R. v Sparrow, [1990] 1 S.C.R. 1075 [Sparrow].

8 Beckman v Little Salmon/Carmacks First Nation, 2010 SCC 53 [Little Salmon].

9 Thank you to Patricia Monture for directing my attention to the changing use of this concept. The analysis here is my own. My first treatment of this topic can be found in Colonial Oppression and the Law: Myth, Voice, Culture and Identity in Aboriginal Rights Discourse (LL.M Thesis, Queen's University, Faculty of Law, 2004) [Unpublished].

10 Kent McNeil, "Reconciliation and the Supreme Court: The Opposing Views of Chief Justices Lamer and McLachlin” (2003) 2 Indigenous LJ 1.

11 Ibid at 3-4.

12 R. v Van der Peet [1996] 2 S.C.R. 507 [Van der Peet].
} 
Professor Mark Walters has also recently examined reconciliation in Aboriginal rights jurisprudence. ${ }^{13}$ Walters conceives of reconciliation in three broad themes and applies Aboriginal rights jurisprudence to those themes. I employ the reverse process in this paper, extracting reconciliation themes from the case law in order to determine how the Court uses its discretion in its reasoning process. All of the themes of reconciliation identified by Walters "involve finding within, or bringing to, a situation of discordance a sense of harmony.", I take no issue with this general understanding of reconciliation. However, it does not reflect the content found in the practice of the Supreme Court of Canada. Indeed, little harmony is brought to Aboriginal/Crown conflicts through the Supreme Court's use of the principle of reconciliation.

I identify three characterizations of reconciliation within the Court's jurisprudence: a "constitutional reconciliation" as applied in Sparrow, a "historical reconciliation" as applied in Van der Peet, and a "contemporary reconciliation" as applied in Gladstone. ${ }^{15}$ Each form of reconciliation creates an unjustified burden on s. 35 rights and each represents a different tool available to Canadian courts to limit Aboriginal rights claims in subtle but devastating ways. Scholars have pointed out the extent to which Canadian law oppresses Aboriginal peoples. ${ }^{16}$ Similarly, my purpose is to reveal the premises and assumptions which the Supreme Court of Canada uses to justify the operation of Aboriginal rights. By becoming more aware of these legal burdens we can identify which areas of Canadian law need a massive re-evaluation and a more honest critique from the Courts before we can even begin to talk about true reconciliation. In the alternative, a true process of reconciliation could very likely embody no role for Canada's courts.

\section{A. Constitutional Reconciliation}

The Supreme Court's original exploration of reconciliation occurred in the 1990 Sparrow decision. ${ }^{17}$ This constitutional reconciliation was focused solely on the duties and powers associated with Crown action. At that time, the Court

13 Mark Walters, "The Jurisprudence of Reconciliation: Aboriginal Rights in Canada" in Will Kymlicka and Bashir Bashir eds, The Politics of Reconciliation in Multicultural Societies (New York: Oxford University Press, 2008) 165.

14

Ibid at 167. Perhaps the most pertinent expression of reconciliation which Walters identifies in Aboriginal rights jurisprudence is what he terms "reconciliation as relationship" which, at 168, he states is "about peace between communities divided by conflict, but it is also about establishing a sense of self-worth or internal peace within those communities."

15 R. v Gladstone [1996] 2 S.C.R. 723 [Gladstone].

16

This literature is extensive, however two of my favorites are Patricia Monture-Angus, supra note 1 and Gordon Christie, "A Colonial Reading of Recent Jurisprudence: Sparrow, Delgamuukw and Haida Nation" (2005) 23 Windsor YB Access Just. 17. Christie offers nine possible models for how the law could have interpreted its relationship with Aboriginal peoples. His conclusion is that the second most restrictive model has been employed in Canada. Christie's analysis and conclusion illustrates that we are engaged in a continuing process of domination which subjects Aboriginal peoples to the whims of the colonial government (now Canada). It is in recognition of this ongoing relationship that I refer to the Supreme Court of Canada as a colonial court.

Walters, supra note 13 at 176, mistakenly identifies Van der Peet as being "the first in a long series of judicial decisions on reconciliation and Aboriginal rights." It is clear that Sparrow, which was decided in 1990, represents the Supreme Court's original exploration of this principle. Perhaps Walters' use of Van der Peet as a starting point represents a distinction of the kind outlined in this paper, that reconciliation as outlined in Sparrow does not directly involve Aboriginal peoples. This is not made clear in his work. 
asserted that "...federal power must be reconciled with federal duty and the best way to achieve that reconciliation is to demand the justification of any government regulation that infringes upon or denies aboriginal rights." "I I term this "constitutional reconciliation" because it is rooted in "federal powers" such as those in section 91(24) which gives the federal government jurisdiction over "Indians, and lands reserved for the Indians", and in "federal duty" which encompasses the fiduciary relationship present between the Crown and Aboriginal peoples. ${ }^{20}$ By reconciling federal powers and federal duties, reconciliation began as a burden placed on the actions of the federal government. Indeed, reconciliation was understood as being a requirement that the federal government justify its infringement on an Aboriginal right. Even though Aboriginal peoples are not directly involved in this process of reconciliation, they are of course certainly impacted by it. As a burden on government actions, reconciliation was cast as a means of protecting Aboriginal rights from unchecked federal power.

But, the reconciliation conceived of in Sparrow produced dangerous consequences for Aboriginal rights. Oddly and ironically, discussions of reconciliation initially came about as a result of justifying limitations on section 35(1) which demands simply that "the existing aboriginal and treaty rights of the aboriginal peoples of Canada are hereby recognized and affirmed.", Section 35 does not include a limitation clause within its terms nor does it fall under section 1 of the Charter. ${ }^{22}$ Since the drafters of the Constitution Act were well aware of limitation clauses, one would expect that in the absence of such a clause there would be no internal limits imposed by the courts upon the existing Aboriginal and treaty rights of the Aboriginal peoples. However, using the principle of reconciliation, the Supreme Court of Canada imported a justification test into the relationship between Aboriginal peoples and the government of Canada. This test allows the colonizer to infringe on Aboriginal rights, as long as it can be justified according to the criteria established by the Supreme Court. ${ }^{23}$ Such a reading of

18 Sparrow, supra note 7 at para 62. The justification test, as laid out in Gladstone, supra note 15 at para 54 requires that "the government must demonstrate that it was acting pursuant to a valid legislative objective" and "the government must demonstrate that its actions are consistent with the fiduciary duty of the government towards aboriginal peoples." Gladstone formed one third of the "Van der Peet trilogy". The third case was R. v N.T.C. Smokehouse Ltd. [1996] 2 S.C.R. 672. Gladstone was a fishing rights case.

19 Constitution Act, 1867 (U.K.), 30 \& 31 Vict. c. 3, s. 91(24) (formerly the British North America Act, 1867) reprinted in R.S.C. 1985, App. II, No. 5.

20 Aboriginal and treaty rights jurisprudence has set out other duties such as the duty to consult Aboriginal peoples. As well, although not a duty in the proper sense, the "honour of the Crown" is a principle which governs Crown action. Also see, Leonard I. Rotman, "Aboriginal Rights: Crown-Native Relations as Fiduciary: Reflections Almost Twenty Years After Guerin" (2003) 22 Windsor YB Access Just 363 (QL) at n 45 where he explains that while the reconciliation in Sparrow was pointed at federal powers, "A similar effect was imposed upon provincial legislative competence in respect of Aboriginal peoples, as indicated in the Court's finding that section 35(1) 'affords Aboriginal peoples constitutional protections against provincial legislative power."' Constitution Act, 1982, s. 35(1) being schedule B to the Canada Act, 1982 (U.K.), 1982, c. 11.

22 Canadian Charter of Rights and Freedoms, Schedule B, Constitution Act, 1982 (U.K.) 1982, c. 11. Charter rights may be limited if the limitation is "demonstrably justified in a free and democratic society".

23 Larry Chartrand, The Political Dimension of Aboriginal Rights (LL.M Thesis, Queen's University, Faculty of Law, 2001) [Unpublished] at 103 he points out that the imposition of a justification test is inconsistent with the Court's prior stance on similar issues. 
section 35(1) could not possibly offer protection for Aboriginal rights and only serves to affirm Crown authority.

Rather than interpret section 35(1) according to the plain language embodied in the Act, the "reading in" of a justification test resulted in the Supreme Court disregarding one of its own rules of interpretation. In Nowegijick, the Supreme Court found that "... treaties and statutes relating to Indians should be liberally construed and doubtful expressions resolved in favour of the Indians." ${ }^{24}$ There is nothing favourable about a justification test which sanctions government infringement of Aboriginal rights. Indeed, without a limitation clause, section 35 (1) ought to have operated as an unreserved recognition of rights. "Recognition" and "affirmation" alone had the potential to introduce a newly prosperous era in Aboriginal/Crown relations. ${ }^{25}$ This potential was destroyed, in part, by the creation of a justification test which relies upon the assumed superiority of the Crown. Rather than merely imposing a burden on federal powers, constitutional reconciliation has become a burden on the full expression of section 35(1) Aboriginal rights.

\section{B. Historical Reconciliation}

A very different kind of reconciliation can be located in Van der Peet. Here, the Court sets out what I term historical reconciliation. In Van der Peet, reconciliation is presented as the reasoning behind section 35(1): "It is...the reconciliation of pre-existing aboriginal claims to the territory that now constitutes Canada, with the assertion of British sovereignty over that territory, to which the recognition and affirmation of aboriginal rights in s.35(1) is directed. ${ }^{, 26}$ Through this form of reconciliation the Court is focused on the historic relationship between Aboriginal peoples and the Crown. While this may be an accurate characterization of the purpose behind s. 35(1), when courts administer reconciliation, it furthers the process of domination experienced by Aboriginal peoples. In Van der Peet this restriction is accomplished by demanding that Aboriginal claims be reconciled with the assertion of British sovereignty. By mere assertion, Crown sovereignty is thus thrust upon Aboriginal people without question, justification or consent. The historical reconciliation set forth in Van der Peet is applied in addition to, rather than in place of, constitutional reconciliation. While reconciliation is thus no longer entirely focused on federal power and federal duty, the Court has retained the justification test.

Historical reconciliation was designed to ensure that the Aboriginal "perspective" is taken into account when considering the definition of an Aboriginal right. But the Court fails to achieve this goal in an equitable manner. The inequality takes shape in the Court's insistence that Aboriginal people accommodate the non-Aboriginal legal system in order to have their rights reconciled with Canadian sovereignty:

Nowegijick v The Queen, [1983] 1 S.C.R. 29, at 36.

Monture-Angus, supra note 1 at 47 where she writes: "'Recognize' means to acknowledge something that already exists. 'Affirm' means to embrace the rights which are now being recognized. To not accept that the words 'recognized and affirmed,' at a minimum, move us beyond thinking that western or European is superior renders the constitutional words meaningless."

26

Supra note 12 at para 36 [emphasis added]. 
The definition of an aboriginal right must, if it is truly to reconcile the prior occupation of Canadian territory by aboriginal peoples with the assertion of Crown sovereignty over that territory, take into account the aboriginal perspective, yet do so in terms which are cognizable to the non-aboriginal legal system. ${ }^{27}$

It is clear that under this system of reconciliation, Aboriginal laws never receive the status that is enjoyed by colonial laws. ${ }^{28}$ Larry Chartrand has noted that the Supreme Court's failure to give equal legal authority to Aboriginal legal systems ensures that "Aboriginal systems must do all the reconciling." ${ }^{29}$ This one-way street immediately casts the legal process of reconciliation in doubt. Indeed, the Supreme Court's failure to receive Aboriginal laws on equal footing with colonial laws does more to entrench the force of colonial law than it does to reconcile competing interests. ${ }^{30}$ As a result, the Court has created conditions in which it cannot actually provide a full recognition and affirmation of Aboriginal laws and rights. This failure is assured despite the Court's recognition of the importance of Aboriginal "perspective" these accommodations that their rights will be recognized and affirmed.

\section{Contemporary Reconciliation}

Another approach to reconciliation can be found in Gladstone. Here, the Court proposes to adopt the definition of reconciliation proposed in Van der Peet. However, the Court went beyond Van der Peet and introduced another conception of reconciliation. Rather than focusing on the past, the Court looks to reconcile contemporary conflicts. Contemporary reconciliation allowed the Court to further entrench limitations on Aboriginal rights. While talking about the participation of non-Aboriginal groups in the fishery as potentially satisfying the standard of infringement, the Court stated: "In the right circumstances, such objectives are in the interest of all Canadians and, more importantly, the reconciliation of aboriginal societies with the rest of Canadian society may well depend on their successful attainment. ${ }^{, 33}$ This adjustment in the definition of reconciliation sees a new limitation being imposed on Aboriginal people. After Gladstone it is necessary to

27 Ibid at para 49 [emphasis added].

For e.g. see R. v Delgamuukw [1997] 3 S.C.R. 1010 (S.C.C.) [Delgamuukw] where the Aboriginal laws are taken merely as evidence rather than as laws which can be interpreted and applied to people and land. Supra note 23 at 82 where Chartrand writes: "Aboriginal rights exist 'within' the legal system of Canada and not equal to it."

30 Peter Fitzpatrick, The Mythology of Modern Law (New York: Routledge, 1992) at 86: "The creation and enforcement of any law is a ritual reassertion of the foundational strength and ordering of the centre. What is being affirmed is not just a particular order in opposition to disorder but the very being and force of order itself." (note omitted)

31 Van der Peet, supra note 12 at para 50 where the Court writes: “...the only just and fair reconciliation is ... one which takes into account the aboriginal perspective while at the same time taking into account the perspective of the common law. True reconciliation will, equally, place weight on each."

32 Gladstone, supra note 15 at para 72-73.

33 Ibid at para 75 
reconcile Aboriginal claims with the "rest of Canadian society." As such, an Aboriginal claim has to be weighed against the needs of non-Aboriginal society.

Has such a process not already been accounted for in the establishment of section 35(1)? Isn't the balancing of Aboriginal and non-Aboriginal interests at the core of constitutional protection of Aboriginal rights? The choice to recognize and affirm Aboriginal rights in s. 35(1) established a path towards balancing the needs, wants and expectations of colonial society while at the same time protecting Aboriginal interests from the domination which accompanies the habituations of colonialism. While not framed in that light, the colonial context gives meaning to s. 35(1). By acknowledging this broader reality, the Supreme Court had the opportunity to give s. 35(1) some meaningful content. To date, the Supreme Court has avoided this path in its interpretation of section 35. Instead, the Court has chosen to retread the familiar path of colonialism. By incorporating the "rest of Canadian society" into the balancing exercise, the Court has expanded the doctrine of reconciliation in a way that further restricts the interpretation of Aboriginal rights. This development thus dictates that the needs of broader Canadian society are an important aspect when defining an Aboriginal right. Such a limitation cannot be justified in the wording of section 35(1).

\section{Reconciliation in Practice}

With 3 variants at its disposal, each of which imposes a particular burden on Aboriginal claims, the Supreme Court has invoked reconciliation discourse explicitly and implicitly in its consideration of Aboriginal claims. One example is found in Delgamuиkw ${ }^{34}$, a landmark decision, where the Court determined the content of Aboriginal title. The Court began by referring to the importance of conservation of fisheries as defined in Sparrow: "The conservation of fisheries ... seeks to reconcile aboriginal societies with the broader community by ensuring that there are fish enough for all., ${ }^{35}$ Here the Court is focusing upon the reconciliation of contemporary interests in order to attend to the needs of both Aboriginal society and "the broader community." As is so often the case, the unstated truths often prove the most poignant. In this instance, the Court fails to consider that even if such conservation does ensure fish for all, such reconciliation also imposes a limitation upon Aboriginal rights which is not justified in s. 35(1). The failing in such a limitation is that the conservation of fisheries results from the imposition of federal power over Aboriginal people, rather than through balancing interests through negotiation.

Constitutional reconciliation, which would demand an examination of the Crown's duties to Aboriginal peoples, recedes from view. Instead, the reconciliation theory advanced in Delgamuukw focuses on federal powers and the needs of broader society. The Court thus ensures that federal power continues to preside over protected rights while nonetheless speaking the language of reconciliation. From here the Court in Delgamuиkw explained that a wide variety of legislative objectives can infringe upon Aboriginal title:

The general principles governing justification laid down in Sparrow, and embellished by Gladstone, operate with respect to

\footnotetext{
Supra note 28.

Ibid at para 161.
} 
infringements of aboriginal title. In the wake of Gladstone, the range of legislative objectives that can justify the infringement of aboriginal title is fairly broad. Most of these objectives can be traced to the reconciliation of the prior occupation of North America by aboriginal peoples with the assertion of Crown sovereignty, which entails that "distinctive aboriginal societies exist within, and are a part of, a broader social, political and economic community". In my opinion, the development of agriculture, forestry, mining, and hydroelectric power, the general economic development of the interior of British Columbia, protection of the environment or endangered species, the building of infrastructure and the settlement of foreign populations to support those aims, are the kinds of objectives that are consistent with this purpose and, in principle, can justify the infringement of aboriginal title.

Strangely, the Court refers to historical reconciliation when undertaking what is clearly an assessment of the possible grounds of contemporary infringement. The inconsistencies that mark the Court's application of the reconciliation principles clearly displays the arbitrariness which underlie Aboriginal rights.

Moreover, by establishing that virtually any type of economic development can potentially infringe Aboriginal rights, the Court appears more concerned with protecting federal powers rather than protecting Aboriginal rights. The Court lost sight of the wording of section 35(1) and has maintained instead, its loyalty to the colonial state. There is nothing in the wording of section 35(1) demanding the Court reconcile any competing claims. Recognition and affirmation do not, on their own, allow the Court to permit any infringement of Aboriginal rights. Quite the contrary. But, by crafting its own reconciliation doctrine, the Court has removed the impetus for a negotiated settlement of Aboriginal claims.

Reconciliation reached new and even more expansive bounds in Justice Binnie's minority judgment in Mitchell v. Canada. Binnie's vision shows the extent to which the Court has diminished the protections enshrined in section 35(1). In an attempt to carry out a contemporary reconciliation Justice Binnie removes the Aboriginal from the Aboriginal interest. Under Binnie's vision, the Aboriginal interest in Mitchell, which involved bringing goods across the CanadaU.S. border without paying customs, was lumped together with those interests of broader society. Binnie begins this process by denying that the Aboriginal claim is compatible with sovereignty of the colonizer. Instead, Binnie chooses to recognize the importance of the Aboriginal claim by relating it to "...national interests that all of us have in common rather than to distinctive interests that for some purposes differentiate an aboriginal community. In my view, reconciliation of these interests in this particular case favours an affirmation of our collective sovereignty." ${ }^{38}$ Behind such a statement lurks the assumption that the colonial government is better positioned to manage the Aboriginal claim as part of "our collective sovereignty" than Aboriginal people are at managing their constitutional rights.

\footnotetext{
36 Ibid at para165 [notes omitted].

37 Mitchell v Canada (Minister of National Revenue - M.N.R.) [2001] 1 S.C.R. 911 [Mitchell]

38 Ibid at para 164.
} 
As Walters' notes, Justice Binnie fails to explain "how or when a legitimate sense of shared sovereignty or common citizenship was forged between Aboriginal and non-Aboriginal Canadians.." ${ }^{, 39}$ Just as Aboriginal peoples and lands are set aside as a separate sphere of federal jurisdiction, Aboriginal rights are protected as distinct rights under a dedicated constitutional provision. By melding the Aboriginal and Crown spheres, Justice Binnie fails to respect the unique position that Aboriginal rights hold in the Constitution. Rather than respecting the limited extent to which "our collective sovereignty" was set out in the Constitution, Binnie stifles the Aboriginal voice by devouring the Aboriginal interest.

Binnie's decision in Mitchell fails to recognize the distinctive political identity of the Aboriginal society which he is judging. He writes: "Whereas historically the Crown may have been portrayed as an entity across the seas with which aboriginal people could scarcely be expected to identify, this was no longer the case in 1982 when the s. 35(1) reconciliation process was established." ${ }^{40}$ Here again a Supreme Court justice neglects the plain language and ultimate purpose of section 35(1) which simply recognizes and affirms Aboriginal rights. Justice Binnie also seems to be working with an understanding that the colonization of Aboriginal peoples was completed in 1982 when he purports that this reconciliation process started. It is not a giant leap from such a false premise to the melding of Aboriginal claims with "national interests" and then on to the assertion that such a melding constitutes a process of reconciliation. In fact, Binnie's reasoning only serves to further disenfranchise Aboriginal people of the rights which had been guaranteed to them.

Larry Chartrand has pointed out the contradiction between the Court's asserted goal of reconciliation and the power structure that gives the Court the ability to make such an assertion: "The courts have held that it is the common law that forms the basis of interpreting Aboriginal rights. In other words, mainstream society has a monopoly over the legal system that is to be the basis for 'reconciling' Aboriginal and non-Aboriginal differences." ${ }^{\text {,11 }}$ This monopoly does not pose a problem for the federal government which asserts that the Supreme Court's decisions "have set the parameters within which reconciliation must occur.",

But, the federal government is not giving itself enough credit. Section 35(1) is an act of reconciliation. Section 35(1) already attempts to reconcile federal duties with federal responsibilities. Section 35(1) represents an act of reconciliation through the decision to simply recognize and affirm Aboriginal rights. The plain language of section 35(1) represents a withdrawal of at least some colonial power

\footnotetext{
Walters, supra note 13 at 179 .

Mitchell, supra note 37 at para 129.

Supra note 23 at 80

Statement by the Delegation of Canada to the Sixth Session of the United Nations Permanent Forum on Indigenous Issues, Agenda Item 3: Special Theme: Territories, Lands and Natural Resources, Delivered by: Daniel Watson, Senior Assistant Deputy Minister, Indian and Northern Affairs Canada. New York, May 16, 2007, online: Indian and Northern Affairs Canada <http://www.ainc-inac.gc.ca/ird/2007/tln_e.html>. Also see Monture-Angus, supra note 1 at 103 where she writes: "The Crown's relationship with Aboriginal people requires a higher standard of conduct even when they are adversaries. To allow litigation and the adversarial nature of this process to exempt the Crown from their obligations to Aboriginal people serves only one purpose and that is to continue to entrench colonial relations."
} 
over Aboriginal lives. Section 35(1) does not establish a reconciliation process to be carried out through the courts. It certainly does not purport to grant the courts such a large responsibility. Indeed, Justice McLachlin was critical of the majority's approach to reconciliation articulated in Van der Peet. In her dissenting opinion, McLachlin saw the Court's use of reconciliation as a political process which lacked precision:

At the broadest reach, whatever the government of the day deems necessary in order to reconcile aboriginal and nonaboriginal interests might pass muster... Upon challenge in the courts, the focus will predictably be on the social justifiability of the measure rather than the rights guaranteed. ${ }^{43}$

Focusing on social justifiability takes the Court away from the main task of ensuring that Aboriginal rights are simply "recognized" and "affirmed." Despite this astute insight into the fact that the process of social justification is a move away from the Court's proper role of protecting guaranteed rights, Justice McLachlin later supported the reconciliation process in Delgamuukw. As recalled from above, the reconciliation process in Delgamuиkw set conditions so demanding as to make it unimaginable how Aboriginal peoples can protect their own title to land.

Ultimately, the expanded role assumed by the Court in importing new criteria and considerations into section 35(1) is stupefying considering that Canadian courts are not even given a role in the reconciliation process as outlined in the Report of the Royal Commission on Aboriginal Peoples [RCAP]. RCAP looks toward "the full participation of the federal government, the provinces and the Aboriginal peoples" to devise "a national policy of reconciliation and regeneration of which we can all be proud." Court has lost the naked racism found in past precedent ${ }^{45}$ but has retained the language of domination, superiority and, in reference to Binnie's declaration of "collective sovereignty," assimilation. The Court is establishing a clear dominance between cultures. In Delgamииkw, reconciliation sanctions non-Aboriginal culture to act in ways that directly infringe upon the Aboriginal connection to the land. At the same time, Aboriginal cultures are forced to accommodate the colonizer's common law, assertions of sovereignty and the needs of broader society. While the Court couches the extensive list of possible grounds of justified infringement in the notion that Aboriginal communities are part of the broader Canadian landscape, the Court does not rationalize this assumption. Aboriginal people sue or defend themselves as Aboriginal peoples and they look for protection for their Aboriginal rights under section 35(1). In such a context, the Court should not reject Aboriginal rights based on "collective sovereignty" or the broader needs of society.

43 Van der Peet, supra note 12 at para 309.

44 Report of the Royal Commission on Aboriginal Peoples, [RCAP] Volume 1, Part One, Chapter 7.2, online:Indian and Northern Affairs Canada <http://www.ainc-inac.gc.ca/ch/r-cap/sg/sg19_e.html\#60>.

45 See e.g. Justice Patterson's decision in R. v Syliboy [1929] 1 D.L.R. 307 (N.S. Co. Ct.), where he discusses the capacity of "savages" to enter into a treaty. For further examples see D'Arcy Vermette "Colonialism and the Process of Defining Aboriginal People", (2008) 31 Dal LJ 211. 


\section{RECONSIDERING RECONCILIATION?}

The development of reconciliation has primarily taken place with regard to the identification, protection and limitation of Aboriginal rights. As discussed in this section, the Supreme Court has more recently used the principle of reconciliation in connection with Crown duties. Holding the Crown to a standard of conduct, through the imposition of duties owed to Aboriginal peoples, is a positive development. While the adequacy of these standards can be debated, the application of legal duties allows Aboriginal/Crown disputes to engage the issues beyond the isolated legal dispute at hand. Perhaps this is a way past the "element of insularity about the Court's approach to the concept of reconciliation." ${ }^{46}$ As an adjudicator of legal rather than political disputes, the Supreme Court will always remain, at its best, only part of the solution. In that sense it will remain somewhat insulated from the broader storm of Aboriginal/Crown disputes. However, without reflection upon the historical, cultural, and political dimensions of the issues at hand, the Court can become a barrier to justice rather than a path to access it. It is necessary for the Court to show flexibility and to ensure that it is accepting of the entire landscape of Aboriginal disputes with the Crown. ${ }^{47}$

As I argued above, the concept of reconciliation has allowed the Court to remain focused on the various ways in which Aboriginal people can accommodate the legal apparatus and norms of the colonizer. ${ }^{48}$ But moving beyond conception to practice, are the duties upon which the Supreme Court relies any more capable of building a path to reconciliation? I would argue that, so far, they are not.

For example, in Haida, ${ }^{49}$ the Supreme Court found that there can be a duty to consult with Aboriginal peoples prior to final claims resolution. This duty can also give rise to a duty to accommodate Aboriginal interests. ${ }^{50}$ The Supreme Court has asserted that the duty to consult requires that the Crown act in an honourable manner which affects the reconciliation "between the Crown and ... Aboriginal peoples" by balancing "societal and Aboriginal interests." Here the Court states: "The Crown may be required to make decisions in the face of disagreement as to the adequacy of its response to Aboriginal concerns. Balance and compromise will

46 Walters, supra note 13 at 176 . Walters describes the Supreme Court's insularity as follows: "It has not considered that concept in light of Aboriginal traditions or the early Crown-Aboriginal treaty relationship. Little or no reference has been made to the emergence of reconciliation within political discourse in Canada. And no mention has been made of the increasing importance of reconciliation to post-conflict situations in other countries, or to the expanding literature on this topic in political science and political theory."

47 For an examination of some of the ways in which Aboriginal peoples voices are underrepresented in the colonial judicial process, see D'Arcy Vermette, “Colonialism and the Suppression of Aboriginal Voice" (2009) 40:2 Ottawa L Rev 225.

48 Gordon Christie, "Delgamuukw and the Protection of Aboriginal Land Interests" (2000-2001) 32 Ottawa L Rev 85 (Q.L.) at para 40, where he writes: "the principle of reconciliation plays out in measures designed to integrate the Aboriginal community into the greater community. For the Crown to satisfy its fiduciary duties to Aboriginal peoples post-Gladstone, the Court requires no more than efforts to work Aboriginal peoples into the greater social, political and economic life of Canada."

Haida Nation v British Columbia (Minister of Forests), 2004 SCC 73 [Haida].

50 Ibid at paras.16-25 where it is explained that the duty to consult and accommodate is rooted in the principle of "the honour of the Crown".

$51 \quad$ Ibid at para 45. 
be necessary." ${ }^{52}$ The Court seems to be divesting itself of the responsibility to reconcile competing claims and, instead, placing this responsibility solely upon the Crown. The problem with such an approach is that the Crown is not in a position to make such a determination with any degree of neutrality or objectivity. ${ }^{53}$ By calling upon the Crown to make final decisions, which are intended to reconcile competing interests, the Court is disregarding $R C A P$ 's call for full participation of Aboriginal peoples. In the context of the duty to consult and accommodate, Haida clearly illustrates that the imposition of Crown authority upon Aboriginal rights remains strong. It is a position which remains fundamentally colonial.

More recently, the Supreme Court's refusal to engage the principle of reconciliation has helped to illustrate how this legal principle functions. $R . v$ $\operatorname{Kapp}^{54}$ was a section 15 equality challenge brought by non-Aboriginal fishermen who challenged a twenty-four hour exclusive fishery designated for Aboriginal fishing. In rejecting the argument challenging the exclusive Aboriginal fishery, the majority decision does not talk about the reconciliation of non-Aboriginal rights with Aboriginal rights. Prior to Kapp, the Court recognized that " $[\mathrm{r}]$ econciliation is not a final legal remedy in the usual sense. Rather, it is a process flowing from rights guaranteed by s. 35(1) of the Constitution Act, 1982." exclusive Aboriginal fishery was established as part of this process. In Kapp, the Supreme Court felt no need to pursue reconciliation as part of its reasoning. Why is it essential that the Supreme Court conduct reconciliation when Aboriginal rights are at issue but reconciliation is not to be conducted when the assertion is about the infringement of non-Aboriginal rights? This answer is as disturbing as it is unrelenting: the continued colonization of Aboriginal peoples.

In getting at this answer, let us consider first McNeil's scathing criticism of the Court's reconciliation process. Chief Justice Lamer's conception of reconciliation which has become the standard practice for the Supreme Court was assessed by McNeil as follows:

...he used it primarily to justify unilateral infringement of Aboriginal rights for the benefit of other Canadians...But if social harmony and peace depend on violation of the constitutional rights of the Aboriginal peoples, what does this say about Canadian society? Are non-Aboriginal Canadians really so mean-spirited? Would we accept violation of our constitutional rights because respect for them might threaten social harmony? Would we not seek to achieve social harmony and peace in ways that did not involve violation of fundamental rights? ? $^{56}$

52 Ibid.

53 Also see, Christie, supra note 48 at para 36 where he writes: "How is it that the Crown, held by the Court to be in a fiduciary position vis-à-vis Aboriginal rights-holders, is licensed to determine courses of action potentially impacting on the rights of these beneficiaries on the basis of measurements involving third parties?"

R. v Kapp, 2008 SCC 41.

55 Haida, supra note 49 at para 32.

$56 \quad$ McNeil, supra note 10 at 17. 
It is clear that the Supreme Court does not consider Aboriginal rights as fundamental rights. The Court has failed to imbue section 35(1) rights with the type of values in which all Canadians can take pride. Aboriginal rights are imbued instead with conflict, rather than framed in a spirit of responsibility. McNeil's question about "our" rights is pertinent here. The rights enshrined within the Constitution exist for the benefit, burden and (to pursue) the collective good of all Canadians. However, the failure of the Courts to effectively honour the obligations in section 35(1) is not a matter of being mean-spirited. It is a matter of being unwilling to make every effort possible to release itself from the processes of colonialism and domination with which Canadian law has grown accustomed. This is evidenced through the Court's unfounded assumption that Aboriginal rights need to be subject to limitation. ${ }^{57}$ The reason why reconciliation is essential for Aboriginal rights, and not for non-Aboriginal claims on the opposing side of the debate, is that the Court does not hold Aboriginal rights in the same esteem as non-Aboriginal rights. Non-Aboriginal rights are held in higher regard and therefore, the Court does not invent or apply arbitrary principles to justify infringing upon them. ${ }^{58}$

Another way in which the Supreme Court selectively uses the doctrines of reconciliation can be found in the recent decision of Little Salmon. Little Salmon which involves the application of the duty to consult in a modern land claims agreement is important because of its timeliness and because of its content (or lack of content) concerning reconciliation. When the Court in Little Salmon dealt with the issue of the duty to consult they revealed the complicit nature of their role in the colonial machine. That role, which was restated in Sparrow, involves ensuring that the colonizing state can operate with all the impunity that it needs in order to carry out its agenda. It is worth recalling that the Supreme Court said in Sparrow that "there was from the outset never any doubt that sovereignty and legislative power, and indeed the underlying title, to such lands vested in the Crown." ${ }^{.59}$ When you combine this list of fallacies with the ways in which legislative power is reinforced in Aboriginal rights discourse (through the doctrine of reconciliation) it is easy to see how a modern land claims agreement will only ever accrue very limited benefits. Still worse is the alternative. Because the Court has consistently reinforced legislative control, Aboriginal interests are doomed unless they do gain a measure of certainty via these modern agreements. It is only when one is immersed in the colonial condition that they would call the benefits attained by the First Nations in the Little Salmon/Carmacks First Nation Final Agreement a "balance of interests" ${ }^{\text {"60 }}$ or as "substantial.","

57

58

Similarly, Larry Chartrand, supra note Manitoba Act, 1870 (1985), 19 D.L.R. (4 $\left.4^{\text {th }}\right) 1$ and comments that "In other contexts where constitutional rights have been violated outside the Charter, the Supreme Court of Canada did not feel compelled to 'read in' a means for the government to nonetheless justify its infringement."

Sparrow, supra note 7 at para 49.

Little Salmon, supra note 8 at para 36-39.

1 Ibid at para 36. And, at para 9 Binnie describes these "substantial" and balanced interests: "Under the Yukon treaties, the Yukon First Nations surrendered their Aboriginal rights in almost 484,000 square kilometres, roughly the size of Spain, in exchange for defined treaty rights in respect of land tenure and a quantum of settlement land (41,595 square kilometres), access to Crown lands, fish and wildlife harvesting, heritage resources, financial compensation, and participation in the management of public resources." 
In Little Salmon, the Supreme Court fails to identify which conception of reconciliation they are using, although reconciliation is referred to repeatedly. ${ }^{62}$ Nonetheless, the colonial nature of the Court is revealed in two primary ways. First, in contrast to the interests of the First Nation, the Court misinterprets the role played by a Yukon resident who is seeking a grant of land within the trapping territory of the First Nation. Second, the absence of doctrine surrounding the Court's use of reconciliation shows us that, in the Court's conception, certain fundamental features of the Crown/Aboriginal relationship have already been reconciled. What and how the Court is willing to reconcile is equally as important as what it is not willing to reconcile.

A Yukon resident and potential private land owner had applied for a land grant within an area of surrendered territory which still carries the burden of the First Nation's hunting and fishing interests. Under the treaty the Crown has the ability to take up such lands from time to time. The main issue in Little Salmon is whether the Crown consulted adequately with the First Nation before granting the land to the Yukon resident. The Supreme Court found that the Crown did in fact discharge its duty to consult.

In determining that the Crown discharged its duty, the majority of the Court, via a decision written by Binnie, once again undermined the community interest of the First Nation. This is done by turning the First Nation into an individual. Binnie's decision contrasts the claim of the Yukon resident with that of the First Nation's trapper who had an entitlement over the lands which were to be granted to the Yukon resident. Binnie directs "considerable importance" to the existence of the claim of the Yukon resident. Further explaining, Binnie says that this application was made "as an ordinary citizen who was entitled to a government decision reached with procedural fairness within a reasonable time. ${ }^{, 64}$ Through this framework Binnie identifies the individual as the standard by which First Nations must adapt. This has damaging consequences for Crown/Aboriginal relations. In contrast to the "ordinary citizen," Binnie explains that "the entitlement of the trapper...was a derivative benefit based on the collective interest of the First Nation of which he was a member." ${ }^{\text {, }}$ The consequence is that Binnie does not feel that the trapper was entitled to represent his own individual interests in the consultation.

On the surface Binnie's conception seems to be giving primacy to the Aboriginal collective. However, in the context of this case he is actually undermining it. The venue of the consultation was the Land Application Review Committee, a committee which was established to handle applications for land grants. It was not a body designed to handle treaty disputes. As a result, one individual (who as an individual was not a party to the treaty) was granted the same procedural voice as a treaty partner (I will not pretend that the Court still views Aboriginal peoples as nations). Treaties were formerly used to exemplify

\footnotetext{
62 See e.g. ibid at paras. $12,40,45,52,55$, and at para 10 where the Court states: "The reconciliation of Aboriginal and non-Aboriginal Canadians in a mutually respectful long-term relationship is the grand purpose of s. 35 of the Constitution Act, 1982".

63 Ibid at para 35 .

64 Ibid.

65 Ibid.
} 
the relationship between the Crown and an Aboriginal People. ${ }^{66}$ Nowadays, if Little Salmon is illustrative, treaties merely represent the relationship between individuals and First Nations. It is necessary to point out that Aboriginal people as Aboriginal Peoples are not represented by the Yukon government (as Binnie contends). ${ }^{67}$ Further, Yukon residents are not voices of the Crown interest. Individual interests do not carry the same weight as that of the Crown or that of the First Nation. If the treaty is to be taken seriously, consultation between the treaty partners also has to be taken seriously. It is not enough to equate an Aboriginal community with an individual and call the duty to consult discharged:

the impact of an administrative decision on the interest of an Aboriginal community, whether or not that interest is entrenched in a s. 35 right, would be relevant as a matter of procedural fairness, just as the impact of a decision on any other community or individual ... may be relevant. ${ }^{68}$

It is with this type of comparison that we see that Binnie's attempt to assimilate Aboriginal people is truly taking shape within Aboriginal rights discourse. Binnie does state that "the First Nation here was consulted as a First Nation through the LARC and not as members of the general public." " However, the very next paragraph belies the truth of the reality that Binnie constructs. Binnie acknowledges that "[i]t is impossible to read the record in this case without concluding that the Paulsen application was simply a flashpoint for the pent-up frustration of the First Nation with the territorial government bureaucracy." ${ }^{, 70}$ Well, if that is the case why does the Crown not seek a solution which would provide a remedy?

The Crown then falls back on notions on administrative law to see if fair procedure was respected. Here notions of fairness are measured by what an individual might want: "the result of disallowing the application would simply be to let the weight of this cumulative problem fall on the head of the hapless Larry Paulsen (who still awaits the outcome of an application filed more than eight years ago). This would be unfair." The duty to consult is not a concept which can be delegated to a body which is actively engaged in determining the immediate material interests of individuals. To understand that consultation merely requires that an individual and the First Nation are granted equal opportunity to express

See for e.g. James [sakéj] Youngblood Henderson, "First Nations' Legal Inheritances in Canada: The Mikmaq Model" (1996) 23 Man LJ 1 at 5 where he writes: "These treaties ... united First Nations directly to the English crown as protected partners." And Simon v The Queen, [1985] 2 S.C.R. 387 at para 24, R. v Badger, [1996] 1 S.C.R. 771 at para 41 and RCAP, supra note 44 Vol. 2, Part One, Chapter 2, section 3.6 where the Commission writes: "The Commission uses the term 'spirit and intent' to mean the intentions the treaty parties voiced during treaty negotiations as the underlying rationale for entering into a treaty and its expected outcome: sharing, coexistence and mutual benefit."

Little Salmon, supra note 8 at para 33 where he writes: "The territorial government, elected in part by Aboriginal people, represents Aboriginal people as much as it does non-Aboriginal people, even though Aboriginal culture and tradition are and will remain distinctive." [emphasis added] 
their interests is to make a mockery of the process called reconciliation. In fact, it undermines the entire treaty process because it reduces the needs and interest of the First Nation to the same level of an individual. Individuals do not sign treaties with the Crown. Nor do First Nations cease to be First Nations (on par with the Crown as treaty partners) simply because they have signed a treaty.

This leads to my second concern with the Little Salmon case. There seems to be no concrete conception of what the Court means by reconciliation. The reason for this is clear. The Court assumes that the goal of the entire reconciliation process is legitimizing Crown occupation in Canada. Further it seems to be operating on the assumption that Aboriginal peoples are seeking, through treaty agreements, the amalgamation of their interests with other interest groups, all of which will be dealt with by the Canadian state. "In Canada, the top prize is cooptation: acceptance by the very club you are criticizing; which is not much of a basis for negotiation if you meant what you said in the first place." ${ }^{\text {"2 }}$ While the Court may state that reconciliation is an ongoing process even after modern treaties are settled, the ease with which it employs simple matters of administrative law to regulate the reconciliation process is illustrative of its ultimate contempt for the status of First Nations as nations. Rather than upset the government bureaucracy the Court forces accommodation and co-optation through the blind application of administrative law. In such a context the stage for reconciliation has been set by the particular methods described earlier in this paper as well as the false premises upon which the Court interprets treaty relationships. For post-treaty agreements the Court can now return to purely legal, rather than political, principles because it has found a way in which these principles now achieve the ultimate goal. The Court has found a way to this goal which pays attention to neither logic nor history but does appeal to the notions of conquest imbedded in the colonial mindset. In Little Salmon the absence of a coherent vision of reconciliation reveals that in the mind of the Court reconciliation has already arrived and its path can be found in the minutiae of Canadian law.

\section{CONCLUSION}

In the end, no matter which version of reconciliation the courts adopt, Aboriginal peoples are forced to deal with the same old clap trap of colonialism. Ultimately, the major development in Canadian law has been in the introduction and continued reliance on the word "reconciliation" itself. Through this word, courts can appear to be making progress while maintaining the status quo, producing yet another distraction to obscure the reality: Canadian courts are talking about and doing the same things to Aboriginal peoples that we more closely associate with (crimes of) the distant past. The judicial principle of reconciliation has been created out of thin air by the Supreme Court of Canada and applied in a manner which ultimately undermines the rights of Aboriginal peoples and continues to engage the colonization of Aboriginal peoples. But is it enough to say that reconciliation continues the colonial process? Can we appreciate what this means?

72 Edgar Friedenberg, Deference to Authority: The Case of Canada (New York: M.E. Sharpe Inc., 1980) at 25. 
The process and practice of colonialism necessarily involves the confiscation, theft, dispossession of Aboriginal peoples' lands, lives, and culture. This is not a mere inconvenience for Aboriginal peoples. Simply put, the law is contributing to the destruction of entire peoples. Colonialism only ends in two ways; either the colonizing State removes its tentacles from Aboriginal lives and lands, or it manages to accomplish the genocide of entire cultures. The Supreme Court of Canada's focus has remained steadfast in ensuring that the colonizing government (the Canadian state) retains control over Aboriginal people(s), resources, and governance. It is an all-encompassing venture and Canada's courts are not merely complicit in this process, they are an integral $\operatorname{cog}$ in the wheel. So, it begs the question, where is the justice and equality that should attend to constitutionally protected Aboriginal rights?

As the law currently stands, there is no justice and we have far too much work to do before we even begin talking about Canadian law bringing about equality. Hopefully, Canada's courts will wake up, take recognition of the damage they are doing, and begin to create law that empowers Aboriginal peoples to resist the dispossession being carried out in this continuing colonial process. One way to do this is to participate to the least extent possible. By simply recognizing and affirming Aboriginal rights the courts could stimulate a new era of negotiations. However, this is now very unlikely. Instead, chances are that, the courts will merely find a new word upon which to tie a seemingly new principle which will be designed to distract us from the process of dispossession which it has become accustomed to defending. Aboriginal peoples can, or should, be able to see through the nonsense of reconciliation brought to us by the courts.

Chrisjohn and Bear Nicholas have assessed the Federal government's attempt at reconciliation in the context of residential schools. Their words are equally relevant to the government's apology as they are to the Court's legal doctrine: "we've been witnessing a made-up ceremony, one where the participants, for various reasons, are trying more to convince themselves they've dealt with all the serious issues rather than actually putting an end to them." ${ }^{, 73}$ The Courts have made a mockery of the Constitutional protections afforded to Aboriginal peoples. It must be remembered that "protection which denies respect is no protection at all." lack of respect stems from the Court's insistence on using rhetoric rather than reasoning. And so it is that we go round and round. We become dizzy (and tired) from the various uses of language and empty doctrine that the courts throw at our peoples. Perhaps colonial powers are banking on us getting confused (or giving up) and losing sight of the access being granted to our lands and resources for the benefit of corporations and governments. Those diligent and dedicated enough to examine this legal nonsense are not confused by it. We are tired of looking at it, analyzing it, and having to unpack the same baggage over and over. But we are not confused.

Supra note 5.

Friedenberg, supra note 72 at Front Jacket. 